DOI: https://doi.org/10.3126/njdrs.v17i0.34954

\title{
Responses to the Covid-19: A Political Economic Analysis
}

\author{
Ratna Mani Nepal, PhD \\ Lecturer at Central Department of Rural Development \\ Tribhuvan University, Kirtipur, Kathmandu \\ Email for correspondence: ratna.nepal@cdrd.tu.edu.np
}

\begin{abstract}
The Covid-19 pandemic posed serious threats to the national and international communities. Worldwide responses to combat its effects seemed weak and controversial. It led individual countries to exercise responses that varied depending upon their tradition, institutions, and leadership. What worked? And what did not? And why is still not comprehended. In this background, this study examines correlation between market economy frameworks such as liberal market economies (LMEs), coordinated market economies (CMEs), state-led market economies (SMEs)and Covid-19 caused deaths. More so, the death cases have been analyzed and interpreted based on published data from worldometer.com as well as national and institutional sources of 23 countries representing three distinct market economy fremeworks. The data is juxtaposed with the acts of right-wing populism that determined decision making and institutional mobilization against Covid-19. The approach is dichotomized with a country's human development index and income inequality index (Gini Index). This study found that a country's market economy framework has had a correlation with the Covid-19 caused deaths The impact, however, was associated with the acts of right-wing populism within different market economies. The 5 selected countries with LMEs have highest; another 5 selected countries with CMEs have higher and 13 selected countries with SMEs have lowest number of deaths. The findings also proves that rate of human development does not appear to be a valid framework for explaining differing death rates between the countries.
\end{abstract}

Key words: Covid-19, responses, HDI, gini index, market economy, South Asia

\section{Introduction}

The Covid-19 pandemic has posed serious threats to the national and international communities. The impact of the pandemic seems to be far reaching. With over 100 million infections, 2 million deaths, and an unconstrained infection capability, the Covid-19 pandemic is more than just a public health crisis. It is a human, economic, and social crisis with global repercussions (Khot \& Nadkar, 2020; Sen, 2020; WHOa, 2020). Despite this being a global crisis, global responses seemed weak and controversial as seen in World Health Organization's response. Therefore, individual countries became the loci of decision making and implementation. As a result, response in containing the coronavirus varied across the countries depending upon their institutions, traditions, and routinized way of decision making (Jasanoff, et. al., 2021).

After nearly one year of the pandemic, what worked and what did not to contain the virus is still uncertain. Political systems such as democracy and autocracy have been ruled out (Fukuyama, 
2020). Covid cases have varying degree of impacts in these two systems. Some democracies have performed well, while not all autocracies succeeded. Neither is exemplary. Rather, right-wing populism that has emerged within these two systems stands closer to the coronavirus spread and its repercussions (Painter, 2020). This is pertinent in the United States of America (USA) and the United Kingdom (UK). In the global south, Brazil and India are a few examples.

Fukuyama (2020) states that state's capacity, social trust and leadership are the major responsible factors in response to coronavirus. These factors have been tested in different countries, however with differing outcomes. World Bank (2020) discussed other factors as multi-sectoral coordination, international linkage, and belief on science, governance and institutions. It means that communities and states both are equally important in combating a pandemic like Covid-19. In some countries, timing for response and simultaneous mobilization of available resources has worked (Gilbert et.al, 2020). Nevertheless, these analyses considered little to political economic perspectives. If patterns in national economy are responsible factors in a country's response to Covid-19 is sparsely discussed.

Given wider empirical literature and public statistics, a country's market economy type seems to be one of the critical variables that have a correlation with Covid-19 cases. Additionally, political economy such as right-wing populism might also have added the complexities. This article aims to examine if a country's market economy structure is an adequate framework to explain a country's success and failures in containing the Covid-19 infections and deaths. The approach is dichotomized with a country's human development index and income inequality index (Gini Index). At the end, a comparative analysis of the Covid-19 infections and deaths in South Asian countries is presented.

For the purpose of examination, 23 selected countries representing three distinct types of market economy have been selected. The country specific data on Covid-19 infections and deaths has been taken from worldometer.com. Statistics concerned with human development index (HDI) and Gini Coefficient are borrowed from UNDP and other multiple sources. While infections are included, a country's level of success in containing the virus spread has been rated on the number of deaths, as deaths are irreversible and show a failure to save a human life.

\section{Market Economy (ME) Framework}

Given political economic perspectives all countries are market economy. The question is which market economy framework a country has adopted. Generally, three types of market economies are discussed; namely liberal market economies (LMEs), coordinated market economy (CMEs) and state-led market economies (SMEs) (Nederveen Pieterse, 2018). The LMEs are typically characterized by short-term oriented company finance, deregulated labor markets, general education, and strong inter-company competition with a principle of putting the market and corporations first (Jackson \& Deeg, 2006). LMEs include countries like the US, the UK, and Chile. CMEs are identified as long-term industrial finance, cooperative industrial relations, high levels of vocational training, and cooperation in technology and standard setting across companies (Jackson \& Deeg, 2006). CMEs typically have high social welfare and job security with the generation of wealth intimately linked to social cohesion, unlike LMEs which focus on stock markets and high returns (Hutton, 1995). CMEs include countries like France, Germany, and Japan. SMEs are characterized by a state-led economic plan and, especially in Asia, are comprised largely of state-owned enterprises, followed by family-run conglomerates, and smaller, family-owned enterprises (Nederveen Pieterse, 2018). SMEs are further read as developmental, 
crony, and extractive types. Public interest tends to rank high in SME development states as part of the overall priority of national development.

In crony SME's, company and industrial finance gets higher priority than the public. The extractive SMEs are led by conservative political and business families. SMEs include countries such as China, Russia, and Rwanda. The countries in South Asia such as India, Pakistan, Bangladesh, and Nepal also fall under SMEs category. The populism is a byproduct of either distorted LME or SME. It emerges with the perceived degeneration of representative democracy (Painter, 2020). It exists in both right-wings as well as left-wing forms. Like LME, the populism places economy first than public interest. It prefers nationalist-protectionist economy which in many cases inclines towards crony and extractives groups. Different MEs place different emphasis on whether private or public interests are the top priority for the country, which helps explaining the varying degree of responses to Covid-19 infections and deaths.

\section{Data Analysis: Responses based on Human Development Index (HDI)}

HDI measures the capability to live a long and healthy life, to acquire knowledge, and to earn income for a basic standard of living (UNDP, 1990). The Gini Index measures income inequality across countries. The data as shown in the tables 1, 2 and 3 reveal that Covid-19 caused deaths has no link with these two variables (Figure 1). This is true if compared with HDI ranks and the Gini coefficient of countries

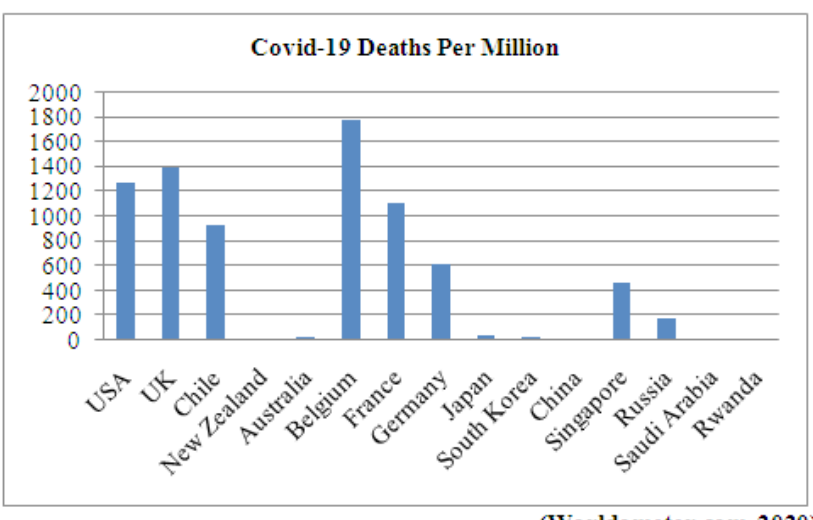

Figure 1. COVID-19 Deaths in Selected Countries both within and outside the same market economy type. There are distractions within each market economy types that cannot be easily explained through HDI or Gini coefficient. Countries with similar HDI rankings have wildly different numbers of deaths e.g. in US and Japan. The inverse is true in the countries with wildly different HDI ranking having similar number of deaths, for example in Rwanda and Norway. The same is true for Gini coefficients. In South Asia, too, a disharmony among HDI, Gini index and Covid-19 caused deaths appear (Table 4). This shows that a country's HDI rank and Gini coefficient are not adequate frameworks to determine a country's response to Covid-19. Hence, human development index (HDI) and Gini index should be ruled out.

Given a general look to the data compiled by worldometer.com, the countries with liberal market economy type have highest, coordinated market economy the higher and state-led market economy the lowest number of deaths ${ }^{1}$. Data show that CMEs have half the number of deaths compared to LMEs. SMEs have less than half the number of deaths than CMEs and nearly a five times lower than the LMEs. This tends to show that Covid-19 caused deaths are linked with patterns in market economy

1 The ratio of the average deaths per million in LMEs, CMEs and SMEs is 716:375:134. The average is taken of the deaths in selected countries within the three market economy type listed in tables 1,2 , and 3

Nepalese Journal of Development and Rural Studies, Volume 17 
practiced by the countries.

\section{Responses Based on Liberal Market Economies (LMEs)}

Given the data as compiled by worldometer.com, the 5 selected countries representing liberal market economies (LMEs) seem to be highly affected by Covid-19 (Table 1). The United States of America is ranked number one in terms of infections and deaths (deaths per million is 1266). The highly developed country having significantly good ranking in terms of HDI has relatively higher Gini coefficient. Yet, the income inequality does not correlate to deaths in the USA while compared to Chile, another LME, which has higher Gini value and the HDI ranking as in a developing country. The United Kingdom reveals similar case. Nevertheless, the New Zealand and Australia present different picture despite that they are LMEs.

Table 1. Covid-19 Infections and Deaths in LMEs

\begin{tabular}{lcccc}
\hline Country & HDI Rank & GNI & Infections/m & Deaths/m \\
USA & 16 & $41.4(2016)$ & 75872 & 1266 \\
UK & 15 & $34.8(2016)$ & 52047 & 1389 \\
Chile & 42 & $44.4(2017)$ & 35668 & 922 \\
New Zealand & 14 & - & 455 & 5 \\
Australia & 6 & $34.4(2013)$ & 1120 & 35 \\
\hline
\end{tabular}

The higher deaths rates in the US and UK tend to bring in to discussion the political ideologies adopted by the two countries and their relationship with the patterns in market economy. Both countries have populist governments led by Donald Trump and Boris Johnson. These leaderships represented right-wing populism by attacking minorities, immigrants and foreign countries. They provoked deregulation and issued tax cuts. Both governments continued attacking democratic institutions.

The political ideology represented by the US and the UK was lucidly reflected during the response period to Covid-19. In the US, it started with denial of the virus and its possible spread. The denial thwarted response preparation in terms of health resource mobilization, counseling and training the front-line workers. It slowed specific health measures issuance process such as physical distancing, wearing mask and use sanitizer (Painter, 2020). Both governments uphold free trade and individualism that led them to thwarter mask wearing to prevent Covid-19 spread. They displayed harmony in denying experts opinion and underestimated the role of science to contain the virus. While the world was shutting down, both governments desired to reopen the economy. In populism, economy matters first than public interest. This shows that the pattern of governance and liberal market economy type in the US and the UK seems correlating with the higher number of deaths by Covid-19.

In contrast, despite being liberal market economy (LMEs), the New Zealand and Chile responded well to Covid-19. The difference is seen in low number of deaths in countries, 5 and 35 deaths per million populations. Reviewers show that strong government intervention and institutions of welfare already in position were the main causes that helped containing the virus spread (WHOb, 2020). In New Zealand government took immediate action to suppress right-wing populism, timely enforced lockdowns, ensured contact tracing and zero tolerance of breaking of shelter-in-place guidelines during the pandemic. Government's actions were tolerated by the mass showing people's strong trust in the state. Critics believe that the state and people relationship is an outcome of pro-people institutions 
of social and economic welfare. In Chile, a left wing socialist government is exercising a reformed constitution that ensures pro-people social and economic programs. Hence, the government responded quickly to the Covid-19 with strict lockdown and quarantine measures. Government's intervention in health resource mobilization and control also showed positive result in controlling the deaths caused by the virus (Court and Correa, 2020).

\section{Responses Based on Coordinated Market Economy (CMEs)}

In CMEs, the virus presence is moderate. Table 2 below also shows a variation in Covid-19 caused deaths in 5 selected countries representing CMEs. Question is why Norway and Germany, and France and South Korea experienced vast differences in Covid-19 deaths despite having similar ranking in HDI.

Table 2. Covid-19 Infections and Deaths in CMEs

\begin{tabular}{lccrc}
\hline Country & HDI Rank & \multicolumn{1}{c}{ GNI } & Infections $/ \mathbf{m}$ & Deaths/m \\
Norway & 1 & $27(2017)$ & 11123 & 100 \\
France & 26 & $31.6(2017)$ & 45719 & 1102 \\
Germany & 4 & $31.9(2016)$ & 25126 & 609 \\
Japan & 19 & $32.9(2013)$ & 2734 & 38 \\
South Korea & 22 & $31.6(2012)$ & 1448 & 26 \\
\hline
\end{tabular}

(Worldometer.com, December/2020)

In France, populism has had a significant presence as seen in 2016 election. The country's economy had been shifted to CME from SME that showed a pro-business sentiment among its population. The Emmanuel Macron's government could not overcome these knots while responding Covid-19. It was seen in delaying in enforcing lockdown measures despite the growth of virus since January 2020. Until then, thousands were already infected and died. In Germany, a pro-business shift has been a trend in recent years. The country has liberalized its economy in recent decades by cutting public expenditures. However, current Angela Merkel government did put public first agenda that significantly helped containing Covid-19 infections and deaths. Germany implemented strict lockdowns, mass testing and contact tracing that had a positive correlation with Covid-19 deaths (Janse \& Tsanova, 2020).

The two Asian giants, Japan and South Korea, demonstrated significantly low Covid-19 impact. Deaths per million populations in the two countries are 26 and 38 respectively. There are similarities in response between the two countries. Both acted quickly to combat the pandemic by enforcing lockdown, mass testing and contact tracing. The leadership showed trust on science and community sentiment. People followed government orders and rules. Mostly significant factor was that neither government turned to populism. Since long, Japan and South Korea are coordinated market economy (CME). In contrast to France and Germany, which showed populist tendency in recent years, Japan and South Korea put public's priority first than economy. This also means that leadership is responsible and has good trust among its pupils. Hence, combating Covid-19 to its low infection and deaths rates became possible.

\section{Responses Based on State-led Market Economy (SMEs)}

SMEs put development in the first priority than economy. The protected economy and investment priority of a state results in mobilizing resources in pursuit of maintaining development Nepalese Journal of Development and Rural Studies, Volume 17 
intact. Despite the fact that there is low Covid-19 effect in 5 selected SMEs representing countries (Table 3), response to the Covid-19 in this market economy varied according to its distinct categories. In developmental SMEs, such as China and Singapore, the rate of infections and deaths is significantly low i.e. 3 and 469 respectively. These economies quickly enacted lockdown, mass testing, and contact tracing. State performed responsibly in confirmation with people's trust. In both countries, past experience of flus such as SARS complemented responses to combat Covid-19. In case of China, the most significant response emerged due to the leadership that acted in coordination with national and international governance machinery. The surveillance mode of governance that China has been practicing in recent years worked in case of containing Covid-19 spread and effects (Shaw, Kim, \& Hau, 2020).

Table 3. Covid-19 Infections and Deaths in SMEs

\begin{tabular}{lcccc}
\hline Country & HDI Rank & GNI & Infections/m & Deaths/m \\
China & 85 & $38.5(2016)$ & 62 & 3 \\
Singapore & 9 & - & 10083 & 469 \\
Russia & 49 & $37.5(2018)$ & 25193 & 181 \\
Saudi Arabia & 36 & - & 10417 & 5 \\
Rwanda & 157 & $43.7(2016)$ & 927 & 12 \\
\hline
\end{tabular}

(Worldometer.com, December/2020)

Rwanda too is a developmental SME which tactically mobilized resources to fix Covid-19 PCR testing charge at one dollar. It controlled infections and deaths rate low (Gilbert, et. al., 2020). In Saudi Arabia, an oligarch com conservative SME, infections turned high (10417), while deaths rate typically low i.e 5 per million population.

South Asian countries. The eightSouth Asian countries represent SMEs with varying distinct categories emerged by history as well as emerging political trends (Table 4). The largest economy in the region is India which represents SME of developmental type. Despite seeming disorder in growth performance, the country stepped up in to a developmental state after its independence in 1947. Pakistan, another greater economy, has been a SME where conservative groups occupy major economic sectors. Nepal, Bangladesh and Sri Lanka tend to be oscillating between oligarch and conservative types of SMEs. These features are the outcome of their transitional political history as well as the policies of economic reform they adopted after 1990.

Table 4. Covid-19 Infections and Deaths in South Asian Countries

\begin{tabular}{lcccc}
\hline Country & HDI & Gini Index & Infections $/ \mathbf{m}$ & Deaths $/ \mathbf{m}$ \\
Afghanistan & 169 & $31(2016)$ & 1384 & 66 \\
Bhutan & 129 & $37.4(2017)$ & 1095 & 1 \\
Bangladesh & 133 & $32.4(2016)$ & 3202 & 48 \\
India & 131 & $35.15(2015)$ & 7658 & 110 \\
Maldives & 95 & $38.4(2009)$ & 27051 & 92 \\
Nepal & 142 & $32.84(2014)$ & 9129 & 67 \\
Pakistan & 154 & $33.5(2015)$ & 2369 & 50 \\
Sri Lanka & 72 & $39.8(2016)$ & 2613 & 13 \\
\hline
\end{tabular}

(Worldometer.com, December/2020, UNDP, 2020)

Against Covid-19 deaths cases (Figure 2), South Asian countries adopted typically similar responses as travel restrictions, banning mass gathering, testing, tracking and treatment. Yet, the 
pandemics outcome depended on the individual country's institutional capacity, time, and leadership's perception of the virus (Stone, 2020).

Bhutan, a tiny state located bordering two giant economies China and India, has been an outlier in in the region. Until December 2020 the country has only one death per million populations. Bhutan's success has been attributed to its timely bold and decisive steps as lockdown, travel ban, and disbursement of public health measures (WHOc, 2020). Bhutan's health sector expense 3 percent of its GDP. Sir Lanka and Maldives showed significant institutional mobilization coupled with timely government actions and pro-people leadership (World Bank, 2020). The Response and Recovery Plan, 2020 was prepared that allowed the government to mobilize state's machinery and coordinate international agencies as required. The plan was flexible so that quick responses could be undertaken whenever was necessary.

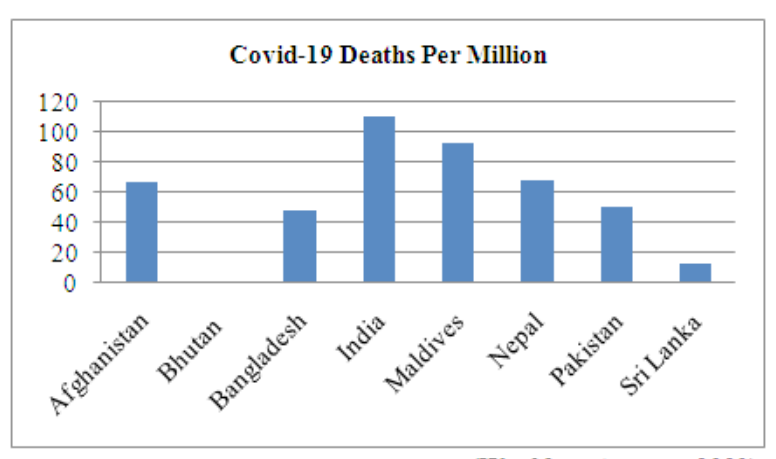

Figure 2. COVID-19 Deaths in South Asian Countries In Maldives, coordination between the national government and local councils worked effectively to implement Covid-19 specific health measures. The country's mass testing rate was highest globally.

Bangladesh and Pakistan have nearly equal number of death per million populations. Both countries represent a long political transition, instability, and ethnic/racial conflicts. This means that despite state-led market economy (SMEs) these countries economy is volatile to extractive and ruling elites. Hence, a mere 2.27 and 2.9 percentage of GDP is expended in public health sector. Since the inception of the pandemic in January, governments responded to Covid-19 cases as early as possible with travel ban, restricting religious gathering, lockdown and testing and tracking. Yet, people hardly trusted the response measures (Chaudhary, Sunna, \& Subrandu, 2020). In a SME of extractive type, state to people trust is often low.

Indian Prime minister Narendra Modi's government is a developmental type SME. It acted earlier against the virus by imposing lockdown and national and international travel ban. Until June, the country could not gear up mass testing due to shortage of resources. Control of mass gathering, contact tracing and testing had been problematic in a country with higher density of population (325 in 2011). The multi-cultural and religiously plural society also affected state's response to the pandemic. India's spending on health sector is only 3.53 percent of its GDP. This means that the country's moderate Covid-19 caused death rates per million populations can be attributed to political measures undertaken than public health system.

Another land locked country of the region, Nepal, has been a SME oscillating between extractive and crony type. This form of economy is also due to the long political transition which is often politically regressive. The conservative extractive groups dominated the economy until 1990. While the country adopted open market economy in the period, a gradual shift in the economy is occurring from SME extractive type to SME crony type. This has had implications in combating the Covid-19. 
During the pandemic, public health institutions seemed undecided and weak in delivering the services. This process was affected by newly formed shadow-institutions which had not had enough vertical as well as horizontal linkages. The formation of High Level Coordination Committee and Covid-19 Crisis Management Committee (CCMC) struggled in delineating responsibilities and actions. In a conservative form of economy, public and state relationship is determined by the leadership's performances. Nepal lacked that potential in the leadership of Prime Minister KP Oli as he often urged traditional health measures as effective tool to contain the virus. It delayed the actions against the virus spread. Moreover, the controversial involvement of some private firms in purchasing health equipment from abroad showed market cronies controlling public health decisions. This has had implications in raising the cost of PCR testing and Covid-19 treatment.

\section{Conclusion}

This study examined if a country's market economy type is responsible factor in determining death rates by Covid-19. For the selected representative countries in three distinct market economy type, namely, liberal market economy (LME), coordinated market economy (CME) and state-led market economy (SME), Covid-19 caused death rates can be partly attributed to the market economy types they have adopted.

The LMEs and CMEs have higher death rates compared to SMEs. However, if a deeper analysis is given in each market economy types, the correlation between market economy and acts of right-wing populism seems to be a better determinant. If a country puts public first, despite its market economy type, its response to combat the Covid-19 has been successful. LMEs put economy first, yet, New Zealand and Australia acted out of the box and hence succeeded in controlling the virus effects. CMEs put public first than economy, however, in France and Germany, government's populist turn affected the response's effectiveness.

Despite the low number of death rates in SMEs, the extractive and crony types lost the battle against Covid-19. In these cases, weak institutions and leadership's conservative perception affected the process. State institutions and leaderships also impacted responses to Covid-19 in South Asia. Prompt actions resulted in quick containing of the virus; delayed actions propagate the virus spread. This also leads the conclusion that state, its institutions, leadership, and social trust matters if a country is to combat pandemic like Covid-19. Meanwhile, this study also concludes, though partly, on the interaction between countries's performance in human development and death rates caused by Covid-19. Rate of human development does not appear to be a valid framework for explaining differing death rates between countries.

\section{References}

Chaudhury, S. R., Sunna, T. C., \& Shubrandu, S. (2020). Response to COVID-19 in Bangladesh: Strategies to resist the growing trend of COVID-19 in a less restricted situation. Asia Pacific Journal of Public Health, 32(8), 471-472.

Court, J. \& Correa, J. T. (2020). Chile's political and institutional response to COVID-19. Retrieved from https://www.theregreview.org/2020/06/24/court-correa-chile-political-institutionalresponse-covid-19/.

Fukuyama, F. (2020). The pandemic and political order: It takes a state. Foreign Affairs. Retrieved from https://www.foreignaffairs.com/print/node/1126047.

Nepalese Journal of Development and Rural Studies, Volume 17 
Gilbert et. al., (2020). Preparedness and vulnerability of African countries against importations of COVID-19: a modelling study. The Lancet, 295. Retrieved from https://doi.org/10.1016/ S0140-6736(20)30411-6

Hutton, W. (1995). The state we're in. London: Random House.

Jackson, G. \& Richard, D. (2006). How many varieties of capitalism? Comparing the comparative institutional analysis of capitalist diversity. Berlin: Max Planck Institute for the Study of Societies, Discussion paper, No. 06/2. Retrieved from https://papers.ssrn.com/sol3/papers. cfm?abstract_id=896384.

Janse, C. A. \& Tsanova, I. (2020). What we can learn from Europe's response to the Covid-19 crisis. Retrieved from https://www.weforum.org/agenda/2020/08/europe-response-covid-19-coronaviruseconomic-crisis-euro-fiscal-monetary-policy-green-deal.

Jasanoff, et. al., (2021). Comparative covid response: Crisis, knowledge, politics (Interim Report). Massachutes: Harvard Kennedy School.

Khot, W. Y., \& Nadkar, M. Y. (2020). The 2019 novel coronavirus outbreak- A global threat. Journal of The Association of Physicians of India, 68. Retrieved from https://pubmed.ncbi.nlm.nih. gov/32138488

Liu, W., Yue, X., \& Tchounwou, P. B. (2020). Response to the COVID-19 epidemic: The Chinese experience and implications for other countries. International Journal of Environmental Research and Public Health, 17(7):DoI:10.3390/ijerph17072304

Maximilian, H., Kackenesch, C., \& Stockemer, D. (2020). Why the corona crisis is particularly difficult for right-wing populist governments. The Current Column. Retrieved fromhttps://www.diegdi.de/en/the-current-column/article/why-the-corona-crisis-is-particularly-difficult-for-rightwing-populist-governments-1/.

Nederveen Pieterse (2018). Multipolar globalization: Emerging economies and development. New York: Routledge.

Painter, A. (2020). How Covid is exposing populism. Retrieved from https:/www.thersa.org/ blog/2020/10/populism-governing-covid

Sen, K. (2020). COVID-19 and socioeconomic impact in Asia: The case of India. Tokyo: United Nations University.

Shaw, R., Kim, Y., \& Hua, J. (2020). Governance, technology and citizen behavior in pandemic: Lessons from COVID-19 in EastAsia. Retrieved from http://dx.doi.org/10.1016/j.pdisas.2020.100090 2590-0617.

Stone, R. (2020). Covid-19 in South Asia: Mirror and catalyst. Asian Affairs, 51(3), 542-568.DoI: $10.1080 / 03068374.2020 .1814078$

UNDP (1990). Human development report, 1990. Retrieved from http://hdr.undp.org/en/reports/global/ hdr1990

UNDP (2020). Human development report, 1990. Retrieved from http://hdr.undp.org/en/reports/global/ hdr1990

WHOa (2020). Coronavirus disease 2019 (COVID-19) (Situation Report -72). Author. 
WHOb (2020). New Zealand takes early and hard action to tackle COVID-19. Retrieved fromhttps:// www.who.int/westernpacific/news/feature-stories/detail/new-zealand-takes-early-and-hardaction-to-tackle-covid-19.

WHOc (2020). Invest in preparedness: Health emergency readiness lessons from Bhutan. Retrieved form https://www.who.int/news-room/feature-stories/detail/invest-in-preparedness-healthemergency-readiness-lessons-from-bhutan.

World Bank (2020). Sri Lanka's Covid-19 response: Saving lives today, preparing for tomorrow. Retrieved from https:/www.worldbank.org/en/results/2020/10/21/sri-lanka-covid-19response-saving-lives-today-preparing-for-tomorrow.

Worldometer.com. Retrieved form https://www.worldometers.info/coronavirus/\#countries

Yadav, R. \& Yadav, A. (2020). Covid-19 under left wing populist Nepali government. International Journal of Innovation, Creativity and Change. Retrieved from https://www.researchgate.net/ publication/344448945_COVID-19_under_Left-wing_Populist_Nepali_Government. 